\title{
Thinking Out of the Box-New Approaches to Controlling GVHD
}

\author{
Frédéric Baron - Stéphanie Humblet-Baron - Grégory Ehx • Sophie Servais • \\ Muriel Hannon - Ludovic Belle - Chantal Lechanteur - Alexandra Briquet • \\ Olivier Giet • Etienne Baudoux • Evelyne Willems • Yves Beguin
}

Published online: 5 January 2014

(C) Springer Science+Business Media New York 2014

\begin{abstract}
Graft-versus-host disease (GVHD) remains a major limitation of allogeneic hematopoietic cell transplantation (allo-HCT). Despite major advances in the understanding of GVHD pathogenesis, standard GVHD prophylaxis regimens continue to be based on the combination of a calcineurin inhibitor with an antimetabolite, while first line treatments still rely on high-dose corticosteroids. Further, no second line treatment has emerged thus far in acute or chronic GVHD patients who failed to respond with corticosteroid treatment. After briefly reviewing current standards of GVHD prevention and treatment, this article will discuss recent approaches that might change GVHD prophylaxis/treatment for decades to come, with a special focus on recently developed immunoregulatory strategies based on infusion of mesenchymal stromal or regulatory T-cells, or injection of lowdose interleukin-2.
\end{abstract}

F. Baron $\cdot$ S. Servais $\cdot$ E. Willems $\cdot$ Y. Beguin

Department of Medicine, Division of Hematology, University and

CHU of Liège, Liège, Belgium

F. Baron · S. Humblet-Baron · G. Ehx $\cdot$ S. Servais $\cdot$ M. Hannon •

L. Belle $\cdot$ Y. Beguin

GIGA I, University of Liège, Liège, Belgium

S. Humblet-Baron

Currently in autoimmune genetics laboratory, University of Leuven, Leuven, Belgium

C. Lechanteur · A. Briquet · O. Giet · E. Baudoux

Laboratory of Cell and Genetic Therapy, University of Liège, Liège, Belgium

F. Baron $(\bowtie)$

Department of Hematology, University of Liège, CHU Sart-Tilman, 4000 Liège, Belgium

e-mail: f.baron@ulg.ac.be
Keywords Allogeneic hematopoietic cell transplantation . Graft-versus-host disease · GVHD · Mesenchymal stromal cells $\cdot$ MSC $\cdot$ Regulatory T-cells $\cdot \mathrm{T}_{\text {reg }} \cdot$ IL-2

\section{Introduction}

Allogeneic hematopoietic cell transplantation (allo-HCT) remains the best treatment option for selected patients with severe primary immune-deficiencies, hemoglobinopathies, severe aplastic anemia, or hematological malignancies [1]. In the latter case, its anti-tumoral efficacy depends not only on high-dose (myeloablative conditioning) or lower-dose (reduced-intensity or nonmyeloablative conditioning) chemo/radiotherapy given during the conditioning regimen, but also on immune-mediated graft-versus-tumor effects [2]. Although mechanisms of graft-versus-tumor effects are not yet fully elucidated, destruction of recipient tumor cells by donor T-cells contained in the graft (and directed against minor or major histocompatibility antigen mismatches between donor and recipient or against tumor-associated antigens) is thought to play a primordial role [3-6]. Unfortunately, donor T-cells contained in the graft can also target healthy recipient tissues and cause graft-versus-host disease (GVHD), a potentially life-threatening complication of allo-HCT [7]. GVHD has been historically separated into two syndromes: acute GVHD, occurring within 100 days after transplantation, and chronic GVHD developing thereafter [8]. However, GVHD with characteristics of the chronic form can occur before day 100 after allo-HCT, while GVHD with characteristics of the acute form may occur beyond day 100, particularly in patients transplanted after nonmyeloablative conditioning and in those given donor lymphocyte infusions. These observations are the basis of a new GVHD classification (NIH classification) that recognized two categories of GVHD: acute $\boldsymbol{G V H D}$, defined as GVHD without signs consistent with 
chronic GVHD and comprising classic acute GVHD occurring before day 100, and late acute GVHD occurring beyond day 100; and chronic GVHD including classic chronic GVHD, defined as chronic GVHD without signs of acute GVHD, and overlap syndrome, in which features of both acute and chronic GVHD coexist [9]. Interestingly, despite a strong association between GVHD and graft-versus-tumor effects [10-12], only milder forms of acute GVHD and NIHdefined chronic GVHD have been associated with improved survival, because of a strong association between severe forms of GVHD and nonrelapse mortality [13, 14]. In this article, we will review current practice and perspectives in GVHD prevention and treatment, with a special focus on innovative cellular therapies.

\section{GVHD Prevention}

\section{Current Practice}

The most efficient way to prevent GVHD consists of in vitro T-cell depletion of the graft. Based on data observed in murine experiments by Dicke et al. in the late $1960 \mathrm{~s}$ [15], hundreds of T-cell depleted allogeneic bone marrow transplantations were performed in the $1980 \mathrm{~s}$ [16]. Methods of T-cell depletion were mainly based on negative selection techniques (by physical separation or antibody-based purging). For example, a number of groups of investigators performed T-cell depletion by combining murine monoclonal antibodies and rabbit complement. This technique allowed a T-cell reduction of 2-3 logs and a low incidence of grade II-IV acute (10-20\%) GVHD, even without any postgrafting immunosuppression [17-19]. However, this benefit was offset by higher incidences of graft rejection/failure, infection (including post-transplant lymphoproliferative disease), and leukemia relapse [16, 19]. In the 1990s, techniques of positive immune-magnetic selection of hematopoietic stem cells (CD34+ cells) were developed concomitantly to the use of G-CSF mobilized peripheral blood stem cells (PBSC) as allogeneic stem cell source. This method allows for a 3-4 $\log$ T-and B-cell depletion and a significant reduction in the incidence of acute and chronic GVHD, without increasing the risk of post-transplant lymphoproliferative disease (probably due to concomitant B-cell depletion) $[20-22,23 \bullet]$. This approach allowed doctors to perform successful allo-HCT across HLA barriers by infusing megadoses of HLA-haploidentical CD34+ selected cells [24]. In the HLA-identical setting, although a recent study suggested similar leukemia-free survival but less chronic GVHD in patients given CD34-selected PBSC in comparison to unmanipulated PBSC [23•], large randomized studies are needed before this approach may become a standard of care for GVHD prophylaxis.
Thus, despite progress in T-cell depletion methods, the current standard of care for GVHD prevention in patients receiving grafts from HLA-matched donors in most transplant centers remains the combination of a calcineurin inhibitor (cyclosporine or tacrolimus) and an antimetabolite [short methotrexate in case of myeloablative transplantation or mycophenolate mofetil (MMF) in case of reduced-intensity or nonmyeloablative transplantation, or in the setting of cord blood transplantation] [25-31]. Although these combinations have been relatively successful at preventing the most severe forms of acute GVHD, they failed to prevent the development of moderate/severe chronic GVHD in a large proportion of patients, and particularly in those given PBSC [32], and/or in those given grafts from unrelated donors [33].

In order to decrease the incidence of moderate/severe chronic GVHD in patients at high risk for this complication, a number of groups have added anti-thymocyte globulin (ATG) to standard GVHD prophylaxis regimens. Recent studies have suggested that the addition of ATG successfully decreased the incidence of chronic GVHD without increasing the risk of relapse both in patients receiving grafts from HLAmatched unrelated donors after myeloablative conditioning and given $60 \mathrm{mg} / \mathrm{kg}$ ATG Fresenius ${ }^{\circledR}$ or $4.5-6.0 \mathrm{mg} / \mathrm{kg}$ ATG Thymoglobulin ${ }^{\circledR}[34-36,37 \bullet \bullet]$, and in those receiving PBSC after reduced-intensity conditioning and given $\leq 5 \mathrm{mg} / \mathrm{kg}$ of ATG Thymoglobulin ${ }^{\circledR}[38]$. In contrast, the use of $\geq 10 \mathrm{mg} / \mathrm{kg}$ ATG Thymoglobulin ${ }^{\circledR}$ was associated with higher risks of disease relapse and infections in patients transplanted after reduced-intensity conditioning [39-41].

\section{New Pharmacological Approaches}

A number of new pharmacological approaches for GVHD prevention are being evaluated. These include in vivo T-cell depletion with alemtuzumab, or the post-transplant use of azacitidine, sirolimus, cyclophosphamide, anti-TNF agents, or bortezomib.

In vivo T-cell depletion with alemtuzumab, a humanized anti-CD52 IgG1 monoclonal antibody with broad lymphocyte-depleting properties, has been extensively studied in patients given grafts after reduced-intensity conditioning, generally combined with cyclosporine [42]. Administration of $100 \mathrm{mg}$ alemtuzumab during the conditioning regimen was very successful at preventing acute and chronic GVHD, but was also associated with higher risks of infection and relapse in patients transplanted for hematological malignancies [14, 43, 44]. Current efforts to prevent relapse with this approach are focusing on decreasing the dose of alemtuzumab, or administering pre-emptive DLI in patients with evidence of poor donor chimerism of minimal residual disease $[45,46]$.

Another recent approach consisted at administering the hypomethylating agent azacitidine post-transplantation. Post- 
transplant azacitidine increased regulatory $\mathrm{T}$-cell $\left(\mathrm{T}_{\text {reg }}\right.$, vide infra) numbers, and thus potentially prevented GVHD, and also induced a cytotoxic CD8+ T-cell response to several tumor antigens including WT1 [47•].

Sirolimus (rapamycin) is a mTOR inhibitor that prevents activation of T-cells by inhibiting their response to IL-2 without affecting $\mathrm{T}_{\text {regs }}$ that respond to IL-2 stimulation mainly by the Stat-5 pathway [48]. Based on encouraging data observed in phase II studies [49, 50], the Blood and Marrow Transplant Clinical Trials Network conducted a large randomized study $(n=304)$ comparing postgrafting immunosuppression with tacrolimus and methotrexate versus tacrolimus plus sirolimus in patients given grafts from HLA-identical siblings after TBIbased myeloablative conditioning. No difference in 114-day acute GVHD-free survival (primary endpoint) was observed, while relapse, nonrelapse mortality and progression-free survival were also similar in the two arms [51].

Taking advantage of the observations that cyclophosphamide is highly cytotoxic to proliferating T-cells but spares resting T-cells and hematopoietic stem cells, the John Hopkins group investigated post-transplant administration of cyclophosphamide as sole immunosuppressive treatment in patients given bone marrow from HLA-matched donors or combined with tacrolimus and MMF administration in those given HLA-haploidentical grafts. Administration of cyclophosphamide $(50 \mathrm{mg} / \mathrm{kg})$ on days +3 and +4 after transplantation allowed a low incidence of each grade III-IV acute (10\%) and chronic (10\%) GVHD in patient given bone marrow from HLA-matched donors [52], while administration of cyclophosphamide $(50 \mathrm{mg} / \mathrm{kg}$ ) on day +3 (with or without a second dose on day +4 ) combined with tacrolimus and mycophenolate mofetil started 1 day after cyclophosphamide administration also produced a low incidence of grade III-IV acute $(6 \%)$ and chronic (25\%) GVHD in patients receiving bone marrow from HLA-haploidentical donors [53]. However, given that post-transplant cyclophosphamide might also kill donor Tcells involved in graft-versus-tumor effects, the impact of post-transplant cyclophosphamide on the relapse risk needs to be further assessed.

TNF- $\alpha$ plays an important role in the initiation of GVHD [54•]. Further, following myeloablative and even nonmyeloablative conditioning regimens, the magnitude of change in the TNF-receptor-1 (TNFR1; a good surrogate for TNF- $\alpha$ ) ratio (day +7 after transplantation/pretransplantation baseline values) has been correlated with later occurrence of acute GVHD $[55,56]$. These observations prompted the development of clinical studies aimed at assessing the impact of TNF- $\alpha$ inhibition on GVHD prevention [57, 58]. Unfortunately, administration of the TNF- $\alpha$ inhibitors infliximab $(10 \mathrm{mg} / \mathrm{kg}$ one day prior to conditioning and then on days 0 , $+7,+14,+28$, and +42 ) or etanercept ( $25 \mathrm{mg}$ twice weekly from start of conditioning to day +56 ) in addition to standard GVHD prophylaxis failed to prevent acute GVHD [57, 58].
Finally, based on extensive murine experiments [59], the proteasome inhibitor bortezomib (on days 1, 4 and 7 after alloHCT) has been assessed in combination with tacrolimus and methotrexate as GVHD prophylaxis in 1-2/10 HLAmismatched unrelated graft recipients in a phase I-II study including 45 patients. Indeed, bortezomib immunomodulatory properties include selective depletion of proliferating alloreactive T-cells while sparing $\mathrm{T}_{\text {regs }}$, and inhibition of antigen-presenting cell activation. Incidences of both grade II-IV (22\%) and chronic (29\%) GVHD were very encouraging [60].

Taken together, these studies suggest that a combination of tacrolimus and sirolimus might be equivalent to standard tacrolimus plus methotrexate in patients given TBI-based conditioning, while in vivo T-cell depletion with alemtuzumab as well as post-transplant azacitidine, cyclophosphamide or bortezomib are promising approaches that should be further investigated in multicenter randomized studies.

\section{New Cellular Approaches}

During the last decade, important advances have been made regarding our knowledge of immunoregulatory cells such as mesenchymal stromal cells (MSC) or $\mathrm{T}_{\text {reg. }}$ MSC are multipotent progenitors that can found within the bone marrow, but also within several connective tissues such as adipose tissue, fetal membranes and the umbilical cord $[61,62,63 \bullet]$. Minimal criteria for MSC definition according to the International Society for Cellular Therapy (ISCT) include: 1) plastic adherence when maintained in standard culture conditions; 2 ) expression of CD105, CD73 and CD90, and lack of expression of CD45, CD34, CD14 or CD11b, CD79alpha or CD19 and HLA-DR surface molecules; and 3) ability to differentiate into osteoblasts, adipocytes and chondrocytes in vitro [64]. MSC have important immunoregulatory properties both in vitro and in vivo, such as inhibition of T-cell proliferation and dendritic cell differentiation, and prolongation of skin or cardiac transplant survival $[63 \bullet, 65,66]$. Our understanding on how MSC impact immune cells has considerably improved over the last decade $[63 \bullet, 66]$. As a result of these studies, MSC are now considered to respond to their immediate environment and adapt their response accordingly through the release of soluble factors, such as prostaglandin E2 (PGE2), IL-10, transforming growth factor beta (TGF- $\beta$ ), nitric oxide (NO), heme oxygenase-1 (HO-1), HLA-G5, hepatocyte growth factor (HGF), bone morphogenetic protein 2 (BMP2), or galectin-1, through induction of indoleamine 2,3 dioxygenase (IDO), and/or through cell contact signaling via Notch and CD95/Fas [63•, 66-68]. Further, contextdependent modification of T-helper (Th)1/Th2 ratio has been shown in several inflammatory disease models [69], while a number of additional studies have demonstrated the ability for MSC to promote/expand $\mathrm{T}_{\text {regs }}$ in vitro and in vivo (mainly 
through TGF- $\beta$ and IDO) and to inhibit the differentiation of pro-inflammatory Th-17 cells (through PGE2) [70]. Finally, In addition to having a plethora of immunoregulatory properties, MSC are hypoimmunogenic, allowing transfer across HLA barriers [63॰], which is mandatory for "off-the-shelf" cellular therapy.

A number of studies have assessed the ability of MSC infusion at preventing GVHD in various murine models of GVHD [71-76], in humanized murine models of xenogeneic GVHD [77, 78], as well as in a preclinical canine model of GVHD [79]. Taken together, these studies suggested that a single injection of (non-activated) MSC given on day 0 failed to prevent GVHD in most models [71, 73, 77, 78], while a single infusion of activated MSC on day 0 [73], or repeated MSC injections at the time of and after transplantation showed clinical benefit in some [72, 76, 77] but not all [74, 75, 78] studies, depending on the GVHD model, the timing of MSC infusion, the dose of MSC infused, as well as the origin of MSC. However, repeated MSC injection failed to prevent lethal GVHD in a pre-clinical canine model of dog leukocyte antigen-haploidentical transplantation [79].

A number of small clinical studies have studied the impact of MSC infusion at the time of allo-HCT on engraftment and GVHD [80-85]. These pilot studies suggested that MSC cotransplantation did not prevent graft rejection in the setting of T-cell repleted transplantation [83, 84], while it might do so in the setting of HLA-haploidentical T-cell depleted allo-HCT [81]. Interestingly, three studies observed a lower incidence of acute GVHD in patients co-transplanted with MSC compared to historical [83, 84] or concurrent [82] controls, suggesting that MSC might help reducing GVHD. However, these results should be taken with caution given the small number of patients included in these pilot studies. Prospective, multicenter, double-blind randomized studies are ongoing in order to assess more definitely the impact of MSC co-transplantation on GVHD (ClinicalTrials.gov Identifier: NCT01045382).

$\mathrm{T}_{\text {reg }}$ play a critical role in the maintenance of tolerance to self-antigens [86 ${ }^{\circ}$. Their development and function requires the transcription factor FoxP3. In the last decade, much attention has been paid to the potential role of $\mathrm{T}_{\text {regs }}$ after allo-HCT. In murine experimental GVHD models, administration of high doses of $\mathrm{T}_{\text {regs }}$ (conventional $\mathrm{T}$ cells $/ \mathrm{T}_{\text {regs }}$ ratio of 1 or 2 ) at the time of transplantation prevented acute GVHD without apparently impairing graft-versus-tumor effects [87-89]. Similarly, a number of studies demonstrated that $\mathrm{T}_{\text {reg }}$ infusion was able to prevent xenogeneic GVHD in humanized mice $[90,91]$. In humans, Di Ianni et al. investigated the ability of $\mathrm{T}_{\text {reg }}$ to allow for infusion of relatively large numbers of conventional T-cells in the HLA-haploidentical setting [92••]. The trial included 28 high-risk adult patients with advanced hematological malignancies. Patients received a myeloablative conditioning regimen, followed by the infusion of freshly isolated donor CD25+ $\mathrm{T}_{\text {regs }}\left(2 \times 10^{6} / \mathrm{kg}\right.$, enriched using a two-step procedure, simultaneous CD8 and CD19 depletion followed by CD25-positive selection) on day-4 before transplantation. Following this preconditioning, patients were transplanted on day 0 with megadoses of CD34+ hematopoietic stem cells to reconstitute the bone marrow and conventional T-cells $\left(0.5-4.0 \times 10^{6}\right.$ cells $\left./ \mathrm{kg}\right)$ to reconstitute the immune system. Immune reconstitution was prompt with $\mathrm{CD} 4+$ and $\mathrm{CD} 8+$ donor T-cell counts reaching the normal range within 2-3 months. Most remarkably, of the 28 patients only two developed at least grade II acute GVHD and none chronic GVHD, despite not using postgrafting immunosuppression and a relatively low $\mathrm{T}_{\text {reg }}$ purity $(80+/-22 \%$ FoxP3-positive cells [93]). In addition, Brunstein et al. investigated the ability of umbilical cord blood-derived $\mathrm{T}_{\text {regs }}\left(0.1-30 \times 10^{5} \quad \mathrm{~T}_{\text {regs }} / \mathrm{kg}\right)$ to decrease the incidence of acute GVHD in 23 adult patients given double umbilical cord blood transplantation [94]. $\mathrm{T}_{\text {regs }}$ were obtained from a third cord blood unit that was 4-6/6 HLA-matched with the recipient and expanded in vitro over 18 days with anti-CD3/antiCD28 monoclonal antibody-coated Dynabeads ${ }^{\circledR}$ and 300 IU/ $\mathrm{mL}$ Il-2. Importantly, the authors observed a lower incidence of grade II-IV acute GVHD in patients given $\mathrm{T}_{\text {regs }}$ than in a group of similarly treated 108 historical patients not given $\mathrm{T}_{\text {regs }}(43 \%$ versus $61 \%, \mathrm{P}=0.05)$. Although very promising, the results should be confirmed in prospective randomized studies.

\section{Treatment of Acute GVHD}

\section{Current Practice}

The standard of care for first line treatment of grade II-IV acute GVHD consists of methylprednisolone (or prednisone) starting at $2 \mathrm{mg} / \mathrm{kg}$ for 7 days with slow subsequent tapering according to GVHD response $[31,95,96 \bullet \bullet$. Nonabsorbable oral corticosteroids (budesonide, $9 \mathrm{mg} /$ day) are often added to systemic corticosteroids in patients with gastrointestinal acute GVHD [97]. Methylprednisolone produces complete responses in 25 to $69 \%$ (53\% in the largest study reported thus far [98]) of patients with grade II-IV acute GVHD [99-102]. Interestingly, one retrospective study suggested that initial treatment with $1 \mathrm{mg} / \mathrm{kg}$ methylprednisolone did not compromise disease control or mortality in patients with grade II acute GVHD [101].

Outcomes for patients with corticosteroid-refractory acute GVHD are dismal, and unfortunately, there is no standard of care for second line treatment of acute GVHD (vide infra) $[96 \bullet \bullet, 103]$.

New Pharmacological Approaches

\section{First Line Treatment}

Many attempts at intensifying the front line treatment for grade II-IV acute GVHD failed. Specifically, the addition of horse ATG, antibodies against IL-2 [basiliximab, daclizumab 
or denileukin diftitox (denileukin)], antibodies against TNF- $\alpha$ (etanercept or infliximab), or pentostatin to (methyl)prednisolone failed to improve response rates, and were often associated with higher nonrelapse mortality [104-108]. A phase II four-arm randomized study was recently conducted with the aim of identifying the most promising agent in addition to standard methylprednisolone for initial therapy for grade II-IV GVHD [109]. Patients were randomized to receive $2 \mathrm{mg} / \mathrm{kg}$ methylprednisolone per day plus etanercept, MMF, denileukin diftitox, or pentostatin. Day 28 complete response rate was the highest with MMF (60\%). Based on this study, the BMT-CTN conducted a multi-center, randomized, double-blind phase III study comparing corticosteroids plus placebo versus corticosteroids plus MMF as initial treatment for acute GVHD [110]. Unfortunately, 56-day GVHD-free survival (primary endpoint) and 6-month survival were similar in the two arms.

In an attempt at avoiding morbidity associated with high doses of corticosteroids, Pidala et al. assessed the ability of sirolimus as initial treatment for grade I $(n=4)$, II $(n=24)$, or III $(n=4)$ acute GVHD [111]. Sixteen of 32 patients (50\%) achieved sustained, complete resolution of acute GVHD, a rate similar to what was observed in matched historical controls treated with standard $1 \mathrm{mg} / \mathrm{kg}$ steroids, suggesting that sirolimus had comparable activity to that of high-dose glucocorticoids in the primary therapy of grade I-III acute GVHD. While encouraging, these results should be confirmed in prospective randomized trials before sirolimus could become a standard of care for initial treatment of moderate acute GVHD.

\section{Second Line Treatment}

Antimetabolites (mycophenolate mofetil or methotrexate), extracorporeal photopheresis, antibodies against IL-2 (basiliximab, daclizumab, inolimomab or denileukin diftitox (denileukin)), antibodies against TNF- $\alpha$ (etanercept or infliximab), alemtuzumab and ATG have been assessed as second line therapy for steroid-refractory acute GVHD (nicely reviewed in reference [96••]). Combining data from 25 clinical studies, 6-month overall survival from initiation of second line therapy (a good surrogate for GVHD response) ranged from 0 to $86 \%$ (weighted average 6-month survival of $49 \%$ ), without evidence that any of these treatments were better or worse than another [96*•]. This was confirmed by a singlecenter retrospective study $(n=93)$ showing similar outcomes in patients with steroid-refractory acute GVHD treated with mycophenolate mofetil, versus inolimomab, or etanercept [112]. In contrast, a multicenter comparative analysis suggested better survival for patients with corticosteroid-refractory grade II acute GVHD treated by extracorporeal photopheresis compared to those treated by anticytokine therapy [113].

\section{New Cellular Approaches}

Currently, cellular approaches for acute GVHD treatment consist primarily of MSC infusion, although a few patients with steroid-refractory acute GVHD have been treated with (in vitro expanded) $\mathrm{T}_{\text {regs }}$ on a compassionate basis by Edinger et al [114]., and in a patient with grade IV acute GVHD by Trzonkowski et al [115]..

\section{First Line Treatment}

A phase II randomized multicenter study has evaluated two different doses of MSC (Prochymal ${ }^{\circledR}$, Osiris Therapeutics, Columbia, MD) given in combination with standard methylprednisolone for the initial therapy for acute GVHD [116]. Thirty-two adult patients with grade II $(n=21)$, grade III $(n=8)$ or grade IV $(n=3)$ acute GVHD were randomized to receive, in addition to standard corticosteroids, two doses of either two or eight million $\mathrm{MSC} / \mathrm{kg}$ each. The first MSC infusion was given within the $48 \mathrm{hr}$ following diagnosis of grade II-IV acute GVHD, and the second 3 days later. Ninety-four percent of patients achieved complete $(77 \%)$ or partial $(16 \%)$ responses. Interestingly, the response rates were comparable in patients given two or eight million MSC $/ \mathrm{kg}$. Based on these encouraging results, a randomized, multicenter, phase III trial compared $2 \times 10^{6} \mathrm{MSC} / \mathrm{kg}$ (Prochymal ${ }^{\circledR}$ ) versus placebo in addition to standard corticosteroid therapy as primary treatment for 184 patients with grade II-IV acute GVHD (ClinicalTrials.gov: NCT00562497). Although the results of the final analysis are not yet published in a peer-reviewed journal, Osiris reported that the trial failed to reach the primary endpoint of durable complete response lasting $\geq 28$ days without any increase in corticosteroid dose nor second line therapy and survival of $\geq 90$ days [117].

\section{Second Line Treatment}

The use of MSC as treatment for steroid-refractory acute GVHD was pioneered by Le Blanc et al. in 2004 [118]. Based on the impressive impact of MSC in a child with steroidrefractory grade IV acute GVHD, the Developmental Committee of the European Group for Blood and Marrow Transplantation developed a phase II study assessing MSC therapy in patients with steroid-refractory acute GVHD [119]. The study included 55 patients with steroid-refractory grades II $(n=5)$, III $(n=25)$ or IV $(n=25)$ acute GVHD (Table 1$)$. Twenty-seven patients received one, 22 two, 4 three, 1 four and 1 five MSC infusions (total of 92 MSC infusions). MSC donors were either HLA-identical siblings $(n=5)$, HLAhaploidentical relatives $(n=18)$, or third-party HLA- 


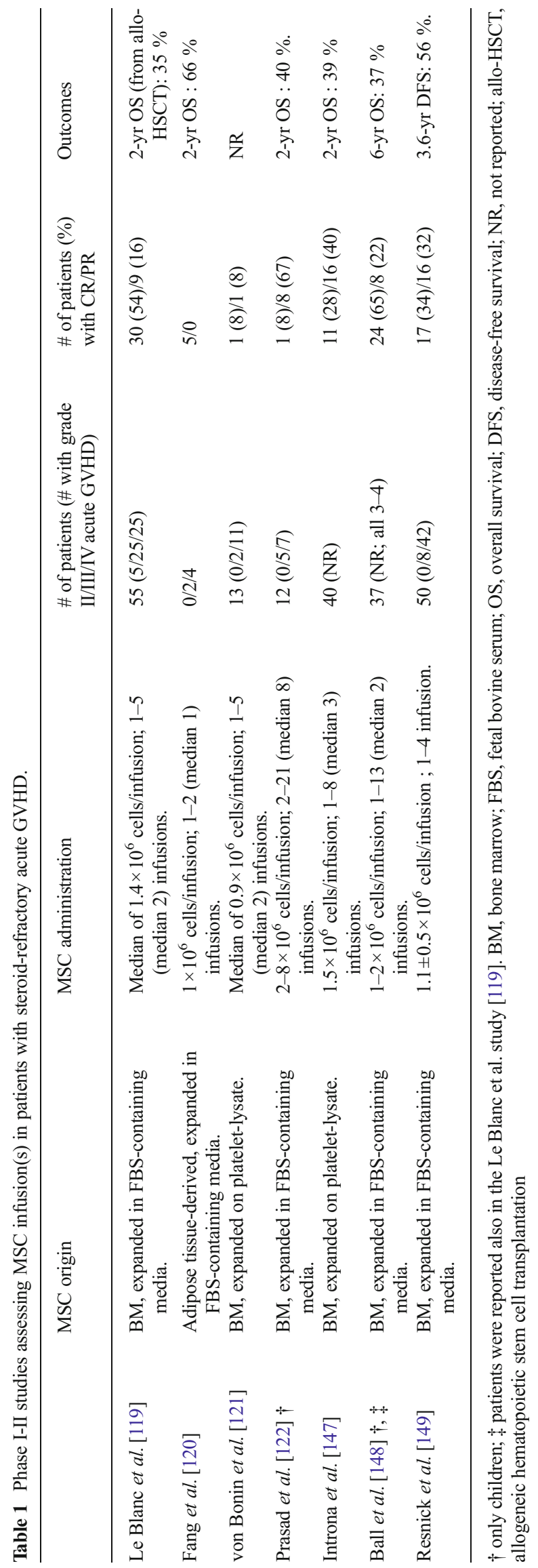

mismatched individuals ( $n=69$ ), and the median dose of MSC infused was 1.4 (range 0.4-9) x $10^{6} \mathrm{MSC} / \mathrm{kg}$. No side effects were seen after MSC infusions. Among the 55 patients, 30 had complete and nine had partial responses. Median time from MSC infusion to complete response was 18 (range, 3-63) days, and responses were more frequently observed in children than in adults. Following this report, a number of phase II studies assessed the impact MSC in patients with steroidrefractory acute GVHD (Table 1) [120-122]. While the majority of these studies suggested efficacy of MSC therapy, it remains to be demonstrated whether MSC infusion provides better results than other second line treatments for acute GVHD.

In an attempt at answering this question, the potential role of MSC (Prochymal ${ }^{\circledR}$ ) was evaluated in addition to standard of care, including institutionally selected second line treatment, in a randomized (2:1) multicentre trial in 244 patients with steroid-refractory grade II-IV gastrointestinal $(n=179)$, skin $(n=144)$, and/or liver $(n=61)$ acute GVHD (ClinicalTrials.gov: NCT00366145). Patients received eight infusions of placebo or $2 \times 10^{6} \mathrm{MSC} / \mathrm{kg}$ each over 4 weeks, with an additional four infusions administered weekly after day 28 in patients who had partial responses. Although the study was completed in 2009, results have been published only in abstract form thus far [123]. Unexpectedly, the study did not observe a significant difference in the rate of overall complete and durable ( $\geq 28$ days) responses between the two groups [primary endpoint; 35 in the MSC versus 30 in the placebo groups $(P=0.3)]$. Incidence of relapse, infection, and toxicities were also comparable in the MSC and placebo arms.

Potential explanations for the discrepancies between phase II studies and the Prochymal ${ }^{\circledR}$ randomized study might be due to differences in immunoregulatory properties between Prochymal and "EBMT" MSC products [124]. Another potential explanation could be that adding MSC to other efficient second line therapy for acute GVHD failed to further improve GVHD responses (indeed the response rates in the second line plus placebo arm of the Prochymal study were as high as $77 \%$ and $68 \%$ for skin and gastrointestinal GVHD, respectively [123]).

\section{Treatment of Chronic GVHD}

Current Practice

Mild chronic GVHD is generally managed by topical treatments. In contrast, first line treatment for moderate/severe forms of chronic GVHD is generally based on corticosteroids, often combined with cyclosporine or tacrolimus [125]. Unfortunately, with these regimens only $20-50 \%$ of patients achieve complete resolution of GVHD and withdrawal of all systemic treatment within 2-3 years $[126,127]$. Further, long- 
term corticosteroid treatment causes numerous complications such as infections, diabetes, myopathy, avascular necrosis, osteoporosis, weight gain with changes in body habitus, cataracts, and emotional lability. These observations led Martin et al. to assess the addition of MMF to standard initial treatment of chronic GVHD in a double-blind multicenter study [126]. The study, unfortunately, did not demonstrate any benefit of adding MMF, with a trend for higher risk of death in patients given MMF (HR 1.9, $95 \%$ CI:0.9-4.3).

Even though several immunosuppressive/ immunomodulating approaches have demonstrated therapeutic activity in steroid-refractory chronic GVHD, the prognosis of patients with such GVHD remains unsatisfactory with 2year survival ranging from 41 to $85 \%$ with salvage therapy [128-130]. There is no standard second line treatment for steroid-refractory chronic GVHD and the "trial-and-error" approach has remained the usual way to identify the drug effective in the individual patient [130]. Second line treatments include immunosuppressors (such as mycophenolate mofetil, methotrexate, alemtuzumab), immunomodulating approaches [such as photopheresis, mTOR inhibition (sirolimus or everolimus), thalidomide], thoraco-abdominal irradiation, antifibrotic agents (imatinib, nilotinib), and rituximab [130].

\section{New Pharmacological Approaches}

As mentioned above, $\mathrm{T}_{\text {regs }}$ play a critical role in the maintenance of tolerance to self-antigens [86•]. Indeed, absence of $\mathrm{T}_{\text {regs }}$ causes fatal autoimmunity in mice and humans [131, 132], while deficits in $T_{\text {reg }}$ function/ number have been observed in various autoimmune/ inflammatory disorders [86•, 133], as well as in GVHD [134, 135]. Interleukin-2 (IL-2) is the critical cytokine regulating $\mathrm{T}_{\text {reg }}$ homeostasis $[136,137]$. Following alloHCT (and particularly in patients with chronic GVHD), there are high amounts of IL-7 and IL-15 that activate conventional CD4+ T-cells [138, 139, 140••], combined with a relative deficit of $\mathrm{IL}-2$ favoring $\mathrm{T}_{\text {reg }}$ apoptosis [140••]. These observations prompted Koreth et al. to conduct a phase 1 dose-escalation study aimed at determining the maximum tolerated dose of daily low-dose subcutaneous IL-2 in patients with steroid-refractory chronic GVHD [141]. Twenty-nine patients were included, and the maximum tolerated dose of IL-2 was $1 \times 10^{6}$ $\mathrm{IU} / \mathrm{m}^{2}$. Remarkably, 12 of 23 evaluable patients achieved an objective partial response during the 8 weeks of IL-2 treatment. Further, IL-2 therapy improved $\mathrm{T}_{\text {reg }}$ homeostasis by increasing $T_{\text {reg }}$ proliferation, $T_{\text {reg }}$ resistance to apoptosis, and $\mathrm{T}_{\text {reg }}$ thymic export $[140 \bullet \bullet]$. Based on these promising results, low-dose $\left(1 \times 10^{6} \mathrm{IU} / \mathrm{m}^{2} /\right.$ day $)$ IL-2 is currently being assessed in patients with steroid-refractory chronic GVHD in a phase II study (ClinicalTrials.gov Identifier: NCT01366092).
New Cellular Approaches

There are few studies published thus far on the impact of MSC infusion in patients with steroid-refractory chronic GVHD. Zhou et al. reported data from four patients with severe sclerodermic chronic GVHD who were given MSC injected directly into the bone marrow at total doses of $1-2 \times 10^{7}$ cells for four to eight infusions within a 22-52 day period [142]. Following MSC infusions, the doses of immunosuppressive medications were tapered significantly, while GVHD symptoms gradually improved in all four patients. More recently, Weng et al. assessed the impact of i.v. MSC infusions in 19 patients with steroid-refractory chronic GVHD [143]. Patients received a median of two (range, one to five) MSC infusions given approximately 6 months apart at a median dose of 0.6 (range, 0.2-1.4) x $10^{6} \mathrm{MSC} / \mathrm{Kg}$. Fourteen of the 19 patients achieved partial $(n=10)$ or complete $(n=4)$ responses. Two-year survival rate from the first MSC infusion was $78 \%$. These two reports might serve as the basis for prospective, double-blind, randomized studies assessing the impact of MSC infusions in patients with steroidrefractory chronic GVHD.

Although $\mathrm{T}_{\text {reg }}$ homeostasis after allo-HCT is not fully understood, it has been demonstrated that even in younger patients, thymic generation of $T_{\text {regs }}$ was minimal while $T_{\text {regs }}$ reconstituted by peripheral expansion of mature $T_{\text {regs }}$ present in the graft and exhibited a predominantly activated/memory phenotype [144]. This was particularly true in older patients given grafts after nonmyeloablative conditioning [145, 146]. Further, it has been observed that $T_{\text {regs }}$ from patients with extensive GVHD had low telomerase activity, thus restricting their proliferative capacities [134], and were more susceptible to apoptosis due to a higher expression of Bim and CD95 and a lower expression of Bcl-2, stressing the interest for administering fresh $\mathrm{T}_{\text {reg }}$ as GVHD therapy. These observations are the basis of ongoing protocols aimed at assessing the feasibility (and efficacy) of $\mathrm{T}_{\text {reg }}$ infusion alone (ClinicalTrials.gov Identifier: NCT01911039) or in combination with sirolimus (ClinicalTrials.gov Identifier: NCT01903473) or low-dose IL2 (ClinicalTrials.gov Identifier: NCT01937468) in patients with steroid-refractory chronic GVHD.

\section{Conclusions}

A number of promising approaches are being evaluated for their potential role in GVHD prophylaxis or treatment. These approaches are focused on depleting alloreactive donor T-cells (alemtuzumab, post-transplant cyclophosphamide) or modulating donor T-cell responses against the recipients (sirolimus, MSC, $\mathrm{T}_{\text {regs }}$, IL-2, bortezomib, azacitidine). With results of phase 2 studies being promising, large multicenter 
randomized studies are needed to help better defining their optimal role in GVHD prevention and/or treatment.

\section{Compliance with Ethics Guidelines}

Conflict of Interest Dr. Frédéric Baron received a consulting fee or honorarium and support for travel to meetings from Genzyme/Sanofi.

Dr. Stéphanie Humblet-Baron, Dr. Grégory Ehx, Dr. Sophie Servais, Dr. Muriel Hannon, Dr. Ludovic Belle, Dr. Chantal Lechanteur, Dr. Alexandra Briquet, Dr. Olivier Gie, Dr. Etienne Baudoux and Dr. Evelyne Willems declare no potential conflicts of interest relevant to this article.

Dr. Yves Beguin received a grant from Milltenyi.

Human and Animal Rights and Informed Consent This article does not contain any studies with human or animal subjects performed by any of the authors.

Grants FB is Senior Research Associate, and GE and LB are Telivie $\mathrm{PhD}$ students at the National Fund for Scientific Research (FNRS) Belgium. SHB is postdoctoral researcher at the Fonds Wetenschappelijk Onderzoek-Vlaanderen (FWO). The review was in part supported by funds from the FNRS, the Belgian Foundation against Cancer (FBC), the anti-cancer foundation from the ULg, the Terry Fox foundation, and the plan cancer from the Belgian Government.

\section{References}

Papers of particular interest, published recently, have been highlighted as

- Of importance

•- Of major importance

1. Baron F, Storb R. Allogeneic hematopoietic cell transplantation as treatment for hematological malignancies: a review. Springer Semin Immunopathol. 2004;26:71-94.

2. Baron F, Storb R. Hematopoietic cell transplantation after reduced-intensity conditioning for older adults with acute myeloid leukemia in complete remission. Curr Opin Hematol. 2007;14: $145-51$.

3. Hobo W, Broen K, van der Velden WJ, Greupink-Draaisma A, Adisty N, Wouters Y, et al. Association of disparities in known minor histocompatibility antigens with relapse-free survival and graft-versus-host disease after allogeneic stem cell transplantation. Biol Blood Marrow Transplant. 2013;19:274-82.

4. Chapuis AG, Ragnarsson GB, Nguyen HN, Chaney CN, Pufnock JS, Schmitt TM, et al. Transferred WT1-reactive CD8+ T cells can mediate antileukemic activity and persist in post-transplant patients. Sci Transl Med. 2013;5:174ra27.

5. Warren EH, Deeg HJ. Dissecting graft-versus-leukemia from graft-versus-host-disease using novel strategies. Tissue Antigens. 2013;81:183-93.

6. Weber G, Gerdemann U, Caruana I, Savoldo B, Hensel NF, Rabin $\mathrm{KR}$, et al. Generation of multi-leukemia antigen-specific T cells to enhance the graft-versus-leukemia effect after allogeneic stem cell transplant. Leukemia. 2013;27:1538-47.

7. Socie G, Blazar BR. Acute graft-versus-host disease: from the bench to the bedside. Blood. 2009;114:4327-36.

8. Sullivan KM. Graft-vs.-host disease. In: Blume KG, Forman SJ, Appelbaum FR, editors. Thomas' hematopoietic cell transplantation. Oxford: Blackwell Publishing Ltd; 2004. p. 635-64.
9. Filipovich AH, Weisdorf D, Pavletic S, Socie G, Wingard JR, Lee SJ, et al. National Institutes of Health consensus development project on criteria for clinical trials in chronic graft-versus-host disease: I. Diagnosis and Staging Working Group report. Biol Blood Marrow Transplant. 2005;11:945-56.

10. Weiden PL, Sullivan KM, Flournoy N, Storb R, Thomas ED, and the Seattle Marrow Transplant Team. Antileukemic effect of chronic graft-versus-host disease. Contribution to improved survival after allogeneic marrow transplantation. $\mathrm{N}$ Engl $\mathrm{J}$ Med. 1981;304:1529-33.

11. Baron F, Maris MB, Sandmaier BM, Storer BE, Sorror M, Diaconescu R, et al. Graft-versus-tumor effects after allogeneic hematopoietic cell transplantation with nonmyeloablative conditioning. J Clin Oncol. 2005;23:1993-2003.

12. Storb R, Gyurkocza B, Storer BE, Sorror ML, Blume K, Niederwieser D, et al. Graft-versus-host disease and graftversus-tumor effects after allogeneic hematopoietic cell transplantation. J Clin Oncol. 2013;31:1530-8.

13. Thepot S, Zhou J, Perrot A, Robin M, Xhaard A, de Latour RP, et al. The graft-versus-leukemia effect is mainly restricted to NIHdefined chronic graft-versus-host disease after reduced intensity conditioning before allogeneic stem cell transplantation. Leukemia. 2010;24:1852-8.

14. Baron F, Labopin M, Niederwieser D, Vigouroux S, Cornelissen JJ, Malm C, et al. Impact of graft-versus-host disease after reduced-intensity conditioning allogeneic stem cell transplantation for acute myeloid leukemia: a report from the Acute Leukemia Working Party of the European group for blood and marrow transplantation. Leukemia. 2012;26:2462-8.

15. Dicke KA, van Hooft JI, van Bekkum DW. The selective elimination of immunologically competent cells from bone marrow and lymphatic cell mixtures. II. Mouse spleen cell fractionating on a discontinuous albumin gradient. Transplantation. 1968;6:562-70.

16. Ho VT, Soiffer RJ. The history and future of T-cell depletion as graft-versus-host disease prophylaxis for allogeneic hematopoietic stem cell transplantation (Review). Blood. 2001;98:3192-204.

17. Prentice HG, Blacklock HA, Janossy G, Gilmore MJML, Price-Jones L, Tidman N, et al. Depletion of T lymphocytes in donor marrow prevents significant graft-versus-host disease in matched allogeneic leukaemic marrow transplant recipients. Lancet. 1984;1:472-6.

18. Martin PJ, Hansen JA, Buckner CD, Sanders JE, Deeg HJ, Stewart $\mathrm{P}$, et al. Effects of in vitro depletion of T cells in HLA-identical allogeneic marrow grafts. Blood. 1985;66:664-72.

19. Maraninchi D, Gluckman E, Blaise D, Guyotat D, Rio B, Pico JL, et al. Impact of T-cell depletion on outcome of allogeneic bonemarrow transplantation for standard-risk leukaemias. Lancet. 1987;2:175-8.

20. Bensinger WI, Buckner CD, Shannon-Dorcy K, Rowley S, Appelbaum FR, Benyunes M, et al. Transplantation of allogeneic CD34+ peripheral blood stem cells in patients with advanced hematologic malignancy. Blood. 1996;88:4132-8.

21. Aversa F, Tabilio A, Velardi A, Cunningham I, Terenzi A, Falzetti F, et al. Treatment of high-risk acute leukemia with T-cell-depleted stem cells from related donors with one fully mismatched HLA haplotype. N Engl J Med. 1998;339:1186-93.

22. Urbano-Ispizua A, Carreras E, Marin P, Rovira M, Martinez C, Fernandez-Aviles F, et al. Allogeneic transplantation of CD34(+) selected cells from peripheral blood from human leukocyte antigen-identical siblings: detrimental effect of a high number of donor CD34(+) cells? Blood. 2001;98:2352-7.

23. - Pasquini MC, Devine S, Mendizabal A, Baden LR, Wingard JR, Lazarus HM, et al. Comparative outcomes of donor graft CD34+ selection and immune suppressive therapy as graft-versus-host disease prophylaxis for patients with acute myeloid leukemia in complete remission undergoing HLA-matched sibling allogeneic hematopoietic cell transplantation. J Clin Oncol. 2012;30:3194 
201. An important comparison of two prospective studies showing similar leukemia-free survival but less chronic GVHD in patients given CD34-selected PBSC in comparison to unmanipulated PBSC.

24. Aversa F, Terenzi A, Tabilio A, Falzetti F, Carotti A, Ballanti S, et al. Full haplotype-mismatched hematopoietic stem-cell transplantation: a phase II study in patients with acute leukemia at high risk of relapse. J Clin Oncol. 2005;23:3447-54.

25. Storb R, Deeg HJ, Whitehead J, Appelbaum F, Beatty P, Bensinger $\mathrm{W}$, et al. Methotrexate and cyclosporine compared with cyclosporine alone for prophylaxis of acute graft versus host disease after marrow transplantation for leukemia. N Engl J Med. 1986;314:729-35.

26. Burroughs L, Mielcarek M, Leisenring W, Sandmaier BM, Maloney DG, Baron F, et al. Extending postgrafting cyclosporine decreases the risk of severe graft-versus-host disease after nonmyeloablative hematopoietic cell transplantation. Transplantation. 2006;81:818-25.

27. Baron F, Sandmaier BM, Storer BE, Maris MB, Langston AA, Lange $T$, et al. Extended mycophenolate mofetil and shortened cyclosporine failed to reduce graft-versus-host disease after unrelated hematopoietic cell transplantation with nonmyeloablative conditioning. Biol Blood Marrow Transplant. 2007;13:1041-8.

28. Brunstein CG, Barker JN, Weisdorf DJ, Defor TE, Miller JS, Blazar $B R$, et al. Umbilical cord blood transplantation after nonmyeloablative conditioning: impact on transplantation outcomes in 110 adults with hematologic disease. Blood. 2007;110:3064-70.

29. Storb R, Antin JH, Cutler C. Should methotrexate plus calcineurin inhibitors be considered standard of care for prophylaxis of acute graftversus-host disease? Biol Blood Marrow Transplant. 2010;16:S18-27.

30. Ostronoff F, Milano F, Gooley T, Gutman JA, McSweeney P, Petersen FB, et al. Double umbilical cord blood transplantation in patients with hematologic malignancies using a reducedintensity preparative regimen without antithymocyte globulin. Bone Marrow Transplant. 2013;48:782-6.

31. Ruutu T, Gratwohl A, de Witte T, Afanasyev B, Apperley J, Bacigalupo A, et al. Prophylaxis and treatment of GVHD: EBMT-ELN working group recommendations for a standardized practice. Bone Marrow Transplant. 2013.

32. Stem Cell Trialists' Collaborative Group. Allogeneic peripheral blood stem-cell compared with bone marrow transplantation in the management of hematologic malignancies: an individual patient data metaanalysis of nine randomized trials. J Clin Oncol. 2005;23:5074-87.

33. Flowers ME, Inamoto Y, Carpenter PA, Lee SJ, Petersdorf EW, Pereira SE, et al. Comparative analysis of risk factors for acute and for chronic graft-versus-host-disease according to National Institute of Health consensus criteria. Blood. 2011;117:3214-9.

34. Deeg HJ, Storer BE, Boeckh M, Martin PJ, McCune JS, Myerson $\mathrm{D}$, et al. Reduced incidence of acute and chronic graft-versus-host disease with the addition of thymoglobulin to a targeted busulfan/ cyclophosphamide regimen. Biol Blood Marrow Transplant. 2006;12:573-84

35. Russell JA, Duan Q, Chaudhry MA, Savoie ML, Balogh A, Turner AR, et al. Transplantation from matched siblings using once-daily intravenous busulfan/fludarabine with thymoglobulin: a myeloablative regimen with low nonrelapse mortality in all but older patients with high-risk disease. Biol Blood Marrow Transplant. 2008;14:888-95.

36. Mohty M, Labopin M, Balere ML, Socie G, Milpied N, Tabrizi R, et al. Antithymocyte globulins and chronic graft-vs-host disease after myeloablative allogeneic stem cell transplantation from HLA-matched unrelated donors: a report from the Societe Francaise de Greffe de Moelle et de Therapie Cellulaire. Leukemia. 2010;24:1867-74.

37. • Socie G, Schmoor C, Bethge WA, Ottinger HD, Stelljes M, Zander $\mathrm{AR}$, et al. Chronic graft-versus-host disease: long-term results from a randomized trial on graft-versus-host disease prophylaxis with or without anti-T-cell globulin ATG-Fresenius. Blood. 2011;117: 6375-82. A propsective phase III study demonstrating that addition of ATG in unrelated graft recipients decreased the incidence of chronic GVHD wihout increasing the risk of relapse.

38. Crocchiolo R, Esterni B, Castagna L, Furst S, El-Cheikh J, Devillier R, et al. Two days of antithymocyte globulin are associated with a reduced incidence of acute and chronic graft-versushost disease in reduced-intensity conditioning transplantation for hematologic diseases. Cancer. 2013;119:986-92.

39. Mohty M, Bay JO, Faucher C, Choufi B, Bilger K, Tournilhac O, et al. Graft-versus-host disease following allogeneic transplantation from HLA-identical sibling with antithymocyte globulin-based reduced-intensity preparative regimen. Blood. 2003;102:470-6.

40. Mohty M, Jacot W, Faucher C, Bay JO, Zandotti C, Collet L, et al. Infectious complications following allogeneic HLA-identical sibling transplantation with antithymocyte globulin-based reduced intensity preparative regimen. Leukemia. 2003;17:2168-77.

41. Michallet M, Le QH, Mohty M, Prebet T, Nicolini F, Boiron JM, et al. Predictive factors for outcomes after reduced intensity conditioning hematopoietic stem cell transplantation for hematological malignancies: a 10-year retrospective analysis from the Societe Francaise de Greffe de Moelle et de Therapie Cellulaire. Exp Hematol. 2008;36:535-44.

42. Chakraverty R, Peggs K, Chopra R, Milligan DW, Kottaridis PD, Verfuerth $\mathrm{S}$, et al. Limiting transplantation-related mortality following unrelated donor stem cell transplantion by using a nonmyeloablative conditioning regimen. Blood. 2002;99:1071-8.

43. Chakrabarti S, Mackinnon S, Chopra R, Kottaridis PD, Peggs K, O'Gorman $\mathrm{P}$, et al. High incidence of cytomegalovirus infection after nonmyeloablative stem cell transplantation: potential role of Campath-1H in delaying immune reconstitution. Blood. 2002;99: 4357-63.

44. Crawley C, Lalancette M, Szydlo R, Gilleece M, Peggs K, Mackinnon S, et al. Outcomes for reduced-intensity allogeneic transplantation for multiple myeloma: an analysis of prognostic factors from the Chronic Leukemia Working Party of the EBMT. Blood. 2005; 105:4532-9.

45. Chakraverty R, Orti G, Roughton M, Shen J, Fielding A, Kottaridis $\mathrm{P}$, et al. Impact of in vivo alemtuzumab dose before reduced intensity conditioning and HLA-identical sibling stem cell transplantation: pharmacokinetics, GVHD, and immune reconstitution. Blood. 2010;116:3080-8.

46. Richardson SE, Khan I, Rawstron A, Sudak J, Edwards N, Verfuerth S, et al. Risk-stratified adoptive cellular therapy following allogeneic hematopoietic stem cell transplantation for advanced chronic lymphocytic leukaemia. Br J Haematol. 2013;160:640-8.

47. - Goodyear OC, Dennis M, Jilani NY, Loke J, Siddique S, Ryan G, et al. Azacitidine augments expansion of regulatory $\mathrm{T}$ cells after allogeneic stem cell transplantation in patients with acute myeloid leukemia (AML). Blood. 2012;119:3361-9. A promising study showing that post-transplant azacitidine administration promoted Treg expansion and the generation of CTL against leukemiaassociated antigens.

48. Zeiser R, Leveson-Gower DB, Zambricki EA, Kambham N, Beilhack A, Loh J, et al. Differential impact of mammalian target of rapamycin inhibition on $\mathrm{CD} 4+\mathrm{CD} 25+\mathrm{Foxp} 3+$ regulatory $\mathrm{T}$ cells compared with conventional CD4+ T cells. Blood. 2008;111:453-62.

49. Armand P, Gannamaneni S, Kim HT, Cutler CS, Ho VT, Koreth J, et al. Improved survival in lymphoma patients receiving sirolimus for graft-versus-host disease prophylaxis after allogeneic hematopoietic stem-cell transplantation with reduced-intensity conditioning. J Clin Oncol. 2008;26:5767-74.

50. Pidala J, Kim J, Jim H, Kharfan-Dabaja MA, Nishihori T, Fernandez $\mathrm{HF}$, et al. A randomized phase II study to evaluate tacrolimus in combination with sirolimus or methotrexate after allogeneic hematopoietic cell transplantation. Haematologica. 2012;97:1882-9. 
51. Cutler C, Logan BR, Nakamura R, Johnston L, Choi SW, Porter DL, et al. Tacrolimus/Sirolimus Vs. Tacrolimus/Methotrexate for graft-vs.-host disease prophylaxis after HLA-matched, related donor hematopoietic stem cell transplantation: results of blood and marrow transplant clinical trials network trial 0402. ASH Annu Meet Abstr. 2012;120.

52. Luznik L, Bolanos-Meade J, Zahurak M, Chen AR, Smith BD, Brodsky R, et al. High-dose cyclophosphamide as single-agent, short-course prophylaxis of graft-versus-host disease. Blood. 2010;115:3224-30.

53. Luznik L, O'Donnell PV, Symons HJ, Chen AR, Leffell MS, Zahurak M, et al. HLA-haploidentical bone marrow transplantation for hematologic malignancies using nonmyeloablative conditioning and high-dose, posttransplantation cyclophosphamide. Biol Blood Marrow Transplant. 2008;14:641-50.

54. - Blazar BR, Murphy WJ, Abedi M. Advances in graft-versus-host disease biology and therapy. Nat Rev Immunol. 2012;12:443-58. A nice review on GVHD pathogeneis.

55. Choi SW, Kitko CL, Braun T, Paczesny S, Yanik G, Mineishi S, et al. Change in plasma tumor necrosis factor receptor 1 levels in the first week after myeloablative allogeneic transplantation correlates with severity and incidence of GVHD and survival. Blood. 2008; $112: 1539-42$

56. Willems E, Humblet-Baron S, Dengis O, Seidel L, Beguin Y, Baron F. Elevations of tumor necrosis factor receptor 1 at day 7 and acute graft-versus-host disease after allogeneic hematopoietic cell transplantation with nonmyeloablative conditioning. Bone Marrow Transplant. 2010;45:1442-8.

57. Hamadani M, Hofmeister CC, Jansak B, Phillips G, Elder P, Blum $\mathrm{W}$, et al. Addition of infliximab to standard acute graft-versus-host disease prophylaxis following allogeneic peripheral blood cell transplantation. Biol Blood Marrow Transplant. 2008;14:783-9.

58. Choi SW, Stiff P, Cooke K, Ferrara JL, Braun T, Kitko C, et al. TNF-inhibition with etanercept for graft-versus-host disease prevention in high-risk HCT: lower TNFR1 levels correlate with better outcomes. Biol Blood Marrow Transplant. 2012;18:1525-32.

59. Sun K, Welniak LA, Panoskaltsis-Mortari A, O’Shaughnessy MJ, Liu H, Barao I, et al. Inhibition of acute graft-versus-host disease with retention of graft-versus-tumor effects by the proteasome inhibitor bortezomib. Proc Natl Acad Sci U S A. 2004;101:8120-5.

60. Koreth J, Stevenson KE, Kim HT, McDonough SM, Bindra B, Armand $\mathrm{P}$, et al. Bortezomib-based graft-versus-host disease prophylaxis in HLA-mismatched unrelated donor transplantation. J Clin Oncol. 2012;30:3202-8.

61. Baron F, Storb R. Mesenchymal stromal cells: a new tool against graft-versus-host disease? Biol Blood Marrow Transplant. 2012;18:822-40.

62. Keating A. Mesenchymal stromal cells: new directions. Cell Stem Cell. 2012;10:709-16.

63. - Le Blanc K, Mougiakakos D. Multipotent mesenchymal stromal cells and the innate immune system. Nat Rev Immunol. 2012;12: 383-96. A nice review on MSC interraction with the immune system.

64. Dominici M, Le BK, Mueller I, Slaper-Cortenbach I, Marini F, Krause D, et al. Minimal criteria for defining multipotent mesenchymal stromal cells. The international society for cellular therapy position statement. Cytotherapy. 2006;8:315-7.

65. Bartholomew A, Sturgeon C, Siatskas M, Ferrer K, McIntosh K, Patil S, et al. Mesenchymal stem cells suppress lymphocyte proliferation in vitro and prolong skin graft survival in vivo. Exp Hematol. 2002;30:42-8.

66. Nauta AJ, Fibbe WE. Immunomodulatory properties of mesenchymal stromal cells. Blood. 2007;110:3499-506.

67. Tolar J, Le Blanc K, Keating A, Blazar BR. Concise review: hitting the right spot with mesenchymal stromal cells. Stem Cells. 2010;28:1446-55.
68. Griffin MD, Elliman SJ, Cahill E, English K, Ceredig R, Ritter T. Adult Mesenchymal Stromal Cell Therapy for Inflammatory Diseases: How Well are We Joining the Dots?. Stem Cells. 2013.

69. Nemeth K, Leelahavanichkul A, Yuen PS, Mayer B, Parmelee A, Doi $\mathrm{K}$, et al. Bone marrow stromal cells attenuate sepsis via prostaglandin $\mathrm{E}(2)$-dependent reprogramming of host macrophages to increase their interleukin-10 production. Nat Med. 2009;15:42-9.

70. Ghannam S, Pene J, Torcy-Moquet G, Jorgensen C, Yssel H. Mesenchymal stem cells inhibit human Th17 cell differentiation and function and induce a T regulatory cell phenotype. J Immunol. 2010;185:302-12.

71. Sudres M, Norol F, Trenado A, Gregoire S, Charlotte F, Levacher $\mathrm{B}$, et al. Bone marrow mesenchymal stem cells suppress lymphocyte proliferation in vitro but fail to prevent graft-versus-host disease in mice. J Immunol. 2006;176:7761-7.

72. Yanez R, Lamana ML, Garcia-Castro J, Colmenero I, Ramirez M, Bueren JA. Adipose tissue-derived mesenchymal stem cells have in vivo immunosuppressive properties applicable for the control of the graft-versus-host disease. Stem Cells. 2006;24:2582-91.

73. Polchert D, Sobinsky J, Douglas G, Kidd M, Moadsiri A, Reina E, et al. IFN-gamma activation of mesenchymal stem cells for treatment and prevention of graft versus host disease. Eur J Immunol. 2008;38:1745-55.

74. Prigozhina TB, Khitrin S, Elkin G, Eizik O, Morecki S, Slavin S. Mesenchymal stromal cells lose their immunosuppressive potential after allotransplantation. Exp Hematol. 2008;36:1370-6.

75. Badillo AT, Peranteau WH, Heaton TE, Quinn C, Flake AW. Murine bone marrow derived stromal progenitor cells fail to prevent or treat acute graft-versus-host disease. $\mathrm{Br} \mathrm{J}$ Haematol. 2008;141:224-34.

76. Christensen ME, Turner BE, Sinfield LJ, Kollar K, Cullup H, Waterhouse NJ, et al. Mesenchymal stromal cells transiently alter the inflammatory milieu post-transplant to delay graft-versus-host disease. Haematologica. 2010;95:2102-10.

77. Tisato V, Naresh K, Girdlestone J, Navarrete C, Dazzi F. Mesenchymal stem cells of cord blood origin are effective at preventing but not treating graft-versus-host disease. Leukemia. 2007;21:1992-9.

78. Bruck F, Belle L, Lechanteur C, De LL, Hannon M, Dubois S, et al. Impact of bone marrow-derived mesenchymal stromal cells on experimental xenogeneic graft-versus-host disease. Cytotherapy. 2013;15:267-79.

79. Mielcarek M, Storb R, Georges GE, Golubev L, Nikitine A, Hwang B, et al. Mesenchymal stromal cells fail to prevent acute graft-versus-host disease and graft rejection after dog-leukocyteantigen haploidentical bone marrow transplantation. Biol Blood Marrow Transplant. 2011;17:214-25.

80. Lazarus HM, Koc ON, Devine SM, Curtin P, Maziarz RT, Holland HK, et al. Cotransplantation of HLA-identical sibling cultureexpanded mesenchymal stem cells and hematopoietic stem cells in hematologic malignancy patients. Biol Blood Marrow Transplant. 2005;11:389-98.

81. Ball LM, Bernardo ME, Roelofs H, Lankester A, Cometa A, Egeler RM, et al. Cotransplantation of ex vivo expanded mesenchymal stem cells accelerates lymphocyte recovery and may reduce the risk of graft failure in haploidentical hematopoietic stemcell transplantation. Blood. 2007;110:2764-7.

82. Ning H, Yang F, Jiang M, Hu L, Feng K, Zhang J, et al. The correlation between cotransplantation of mesenchymal stem cells and higher recurrence rate in hematologic malignancy patients: outcome of a pilot clinical study. Leukemia. 2008;22:593-9.

83. Baron F, Lechanteur C, Willems E, Bruck F, Baudoux E, Seidel L, et al. Cotransplantation of mesenchymal stem cells might prevent death from graft-versus-host disease (GVHD) without abrogating graft-versus-tumor effects after HLA-mismatched allogeneic 
transplantation following nonmyeloablative conditioning. Biol Blood Marrow Transplant. 2010;16:838-47.

84. Bernardo ME, Ball LM, Cometa AM, Roelofs H, Zecca M, Avanzini MA, et al. Co-infusion of ex vivo-expanded, parental MSCs prevents life-threatening acute GVHD, but does not reduce the risk of graft failure in pediatric patients undergoing allogeneic umbilical cord blood transplantation. Bone Marrow Transplant. 2011;46:200-7.

85. Wu Y, Wang Z, Cao Y, Xu L, Li X, Liu P, et al. Cotransplantation of haploidentical hematopoietic and umbilical cord mesenchymal stem cells with a myeloablative regimen for refractory/relapsed hematologic malignancy. Ann Hematol. 2013.

86. - Tian L, Humblet-Baron S, Liston A. Immune tolerance: are regulatory T cell subsets needed to explain suppression of autoimmunity? Bioessays. 2012;34:569-75. A nice review on Treg and Treg subsets.

87. Cohen JL, Trenado A, Vasey D, Klatzmann D, Salomon BL. $\mathrm{CD} 4(+) \mathrm{CD} 25(+)$ immunoregulatory T cells: new therapeutics for graft-versus-host disease. J Exp Med. 2002;196:401-6.

88. Edinger M, Hoffmann P, Ermann J, Drago K, Fathman CG, Strober $\mathrm{S}$, et al. CD4+CD25+ regulatory $\mathrm{T}$ cells preserve graftversus-tumor activity while inhibiting graft-versus-host disease after bone marrow transplantation. Nat Med. 2003;9:1144-50.

89. Colonna L, Sega EI, Negrin RS. Natural and expanded $\mathrm{CD} 4(+) \mathrm{CD} 25(+)$ regulatory $\mathrm{T}$ cells in bone marrow transplantation. Biol Blood Marrow Transplant. 2011;17:S58-62.

90. Hippen KL, Merkel SC, Schirm DK, Sieben CM, Sumstad D, Kadidlo DM, et al. Massive ex vivo expansion of human natural regulatory T cells (T(regs)) with minimal loss of in vivo functional activity. Sci Transl Med. 2011;3:83ra41.

91. Hannon M, Lechanteur C, Lucas S, Somja J, Seidel L, Belle L, et al. Infusion of clinical-grade enriched regulatory $\mathrm{T}$ cells delays experimental xenogeneic graft-versus-host disease. Transfusion. 2013. doi:10.1111/trf.12279.

92. •- Di Ianni M, Falzetti F, Carotti A, Terenzi A, Castellino F, Bonifacio E, et al. Tregs prevent GVHD and promote immune reconstitution in HLA-haploidentical transplantation. Blood. 2011;117:3921-8. This article demonstrate that Treg infusion can prevent acute GVHD in human patients given hematopoietic stem cells and conventional Tcells from HLA-haploidentical donors.

93. Di Ianni M, Del PB, Zei T, Iacucci OR, Cecchini D, Cantelmi MG, et al. $T$ regulatory cell separation for clinical application. Transfus Apher Sci. 2012;47:213-6.

94. Brunstein CG, Miller JS, Cao Q, McKenna DH, Hippen KL, Curtsinger J, et al. Infusion of ex vivo expanded T regulatory cells in adults transplanted with umbilical cord blood: safety profile and detection kinetics. Blood. 2011;117:1061-70.

95. Van Lint MT, Uderzo C, Locasciulli A, Majolino I, Scime R, Locatelli F, et al. Early treatment of acute graft-versus-host disease with high- or low-dose 6-methylprednisolone: a multicenter randomized trial from the Italian Group for Bone Marrow Transplantation. Blood. 1998;92:2288-93.

96. • Martin PJ, Rizzo JD, Wingard JR, Ballen K, Curtin PT, Cutler C, et al. First- and second-line systemic treatment of acute graft-versushost disease: recommendations of the American Society of Blood and Marrow Transplantation. Biol Blood Marrow Transplant. 2012;18: 1150-63. An important review on current treatment of acute GVHD.

97. Ibrahim RB, Abidi MH, Cronin SM, Lum LG, Al-Kadhimi Z, Ratanatharathorn $\mathrm{V}$, et al. Nonabsorbable corticosteroids use in the treatment of gastrointestinal graft-versus-host disease. Biol Blood Marrow Transplant. 2009;15:395-405.

98. MacMillan ML, Defor TE, Weisdorf DJ. The best endpoint for acute GVHD treatment trials. Blood. 2010;115:5412-7.

99. Martin PJ, Schoch G, Fisher L, Byers V, Anasetti C, Appelbaum $\mathrm{FR}$, et al. A retrospective analysis of therapy for acute graftversus-host disease: initial treatment. Blood. 1990;76:1464-72.

100. MacMillan ML, Weisdorf DJ, Wagner JE, Defor TE, Burns LJ, Ramsay NK, et al. Response of 443 patients to steroids as primary therapy for acute graft-versus-host disease: comparison of grading systems. Biol Blood Marrow Transplant. 2002;8:387-94.

101. Mielcarek M, Storer BE, Boeckh M, Carpenter PA, McDonald GB, Deeg HJ, et al. Initial therapy of acute graft-versus-host disease with low-dose prednisone does not compromise patient outcomes. Blood. 2009;113:2888-94.

102. Inamoto Y, Martin PJ, Storer BE, Mielcarek M, Storb RF, Carpenter PA. Response endpoints and failure-free survival after initial treatment for acute graft-versus-host disease. Haematologica. 2013.

103. Deeg HJ. How I, treat refractory acute GVHD. Blood. 2007;109: 4119-26.

104. Cahn JY, Bordigoni P, Tiberghien P, Milpied N, Brion A, Widjenes $\mathrm{J}$, et al. Treatment of acute graft-versus-host disease with methylprednisolone and cyclosporine with or without an anti-interleukin-2 receptor monoclonal antibody. A multicenter phase III study. Transplantation. 1995;60:939-42.

105. Cragg L, Blazar BR, DeFor T, Kolatker N, Miller W, Kersey J, et al. A randomized trial comparing prednisone with antithymocyte globulin/prednisone as an initial systemic therapy for moderately severe acute graft-versus-host disease. Biol Blood Marrow Transplant. 2000;6:441-7.

106. Lee SJ, Zahrieh D, Agura E, MacMillan ML, Maziarz RT, McCarthy Jr PL, et al. Effect of up-front daclizumab when combined with steroids for the treatment of acute graft-versus-host disease: results of a randomized trial. Blood. 2004;104:1559-64.

107. Levine JE, Paczesny S, Mineishi S, Braun T, Choi SW, Hutchinson RJ, et al. Etanercept plus methylprednisolone as initial therapy for acute graft-versus-host disease. Blood. 2008;111:2470-5.

108. Couriel DR, Saliba R, de Lima M, Giralt S, Andersson B, Khouri I, et al. A phase III study of infliximab and corticosteroids for the initial treatment of acute graft-versus-host disease. Biol Blood Marrow Transplant. 2009;15:1555-62.

109. Alousi AM, Weisdorf DJ, Logan BR, Bolanos-Meade J, Carter S, Difronzo N, et al. Etanercept, mycophenolate, denileukin, or pentostatin plus corticosteroids for acute graft-versus-host disease: a randomized phase 2 trial from the Blood and Marrow Transplant Clinical Trials Network. Blood. 2009;114:511-7.

110. Bolanos-Meade J, Logan BR, Alousi AM, Antin JH, Barowski K, Carter SL, et al. A multi-center, randomized, double blind, phase III clinical trial comparing steroids/placebo vs. steroids/ mycophenolate mofetil as initial therapy for acute graft-versushost disease. Blood and Marrow Transplant Clinical Trials Network Study 0802. Biol Blood Marrow Transplantat J Am Soc Blood Marrow Transplant. 2013;19(2):S137.

111. Pidala J, Tomblyn M, Nishihori T, Field T, Ayala E, Perkins J, et al. Sirolimus demonstrates activity in the primary therapy of acute graft-versus-host disease without systemic glucocorticoids. Haematologica. 2011;96:1351-6.

112. Xhaard A, Rocha V, Bueno B, de Latour RP, Lenglet J, Petropoulou A, et al. Steroid-refractory acute GVHD: lack of long-term improved survival using new generation anticytokine treatment. Biol Blood Marrow Transplant. 2012;18:406-13.

113. Jagasia M, Greinix H, Robin M, Das-Gupta E, Jacobs R, Savani $\mathrm{BN}$, et al. Extracorporeal photopheresis versus anticytokine therapy as a second-line treatment for steroid-refractory acute GVHD: a multicenter comparative analysis. Biol Blood Marrow Transplant. 2013;19:1129-33.

114. Edinger M, Hoffmann P. Regulatory T cells in stem cell transplantation: strategies and first clinical experiences. Curr Opin Immunol. 2011;23:679-84.

115. Trzonkowski P, Bieniaszewska M, Juscinska J, Dobyszuk A, Krzystyniak A, Marek N, et al. First-in-man clinical results of the treatment of patients with graft versus host disease with human ex vivo expanded CD4+CD25+C. Clin Immunol. 2009;133:22-6.

116. Kebriaei P, Isola L, Bahceci E, Holland K, Rowley S, McGuirk J, et al. Adult human mesenchymal stem cells added to corticosteroid 
therapy for the treatment of acute graft-versus-host disease. Biol Blood Marrow Transplant. 2009;15:804-11.

117. Allison M. Genzyme backs Osiris, despite Prochymal flop. Nat Biotechnol. 2009;27:966-7.

118. Le Blanc K, Rasmusson I, Sundberg B, Gotherstrom C, Hassan M, Uzunel $\mathrm{M}$, et al. Treatment of severe acute graft-versus-host disease with third party haploidentical mesenchymal stem cells. Lancet. 2004;363:1439-41.

119. Le Blanc K, Frassoni F, Ball L, Locatelli F, Roelofs H, Lewis I, et al. Mesenchymal stem cells for treatment of steroid-resistant, severe, acute graft-versus-host disease: a phase II study. Lancet. 2008;371:1579-86.

120. Fang B, Song Y, Liao L, Zhang Y, Zhao RC. Favorable response to human adipose tissue-derived mesenchymal stem cells in steroidrefractory acute graft-versus-host disease. Transplant Proc. 2007;39:3358-62.

121. von Bonin M, Stolzel F, Goedecke A, Richter K, Wuschek N, Holig K, et al. Treatment of refractory acute GVHD with thirdparty MSC expanded in platelet lysate-containing medium. Bone Marrow Transplant. 2009;43:245-51.

122. Prasad VK, Lucas KG, Kleiner GI, Talano JA, Jacobsohn D, Broadwater G, et al. Efficacy and safety of ex-vivo cultured adult human mesenchymal stem cells (Prochymal(TM)) in pediatric patients with severe refractory acute graft-versus-host disease in a compassionate use study. Biol Blood Marrow Transplant. 2011;17:534-41.

123. Martin PJ, Uberti JP, Soiffer RJ, Klingemann H, Waller EK, Daly AS, et al. Prochymal improves response rates in patients with steroid-refractory acute graft versus host disease (SR-GVHD) involving the liver and gut: results of a randomized, placebocontrolled, multicenter phase III trial in GVHD. Biol Blood Marrow Transplant. 2010;16:S169-70.

124. Galipeau J. The mesenchymal stromal cells dilemma-does a negative phase III trial of random donor mesenchymal stromal cells in steroid-resistant graft-versus-host disease represent a death knell or a bump in the road? Cytotherapy. 2013;15:2-8.

125. Wolff D, Gerbitz A, Ayuk F, Kiani A, Hildebrandt GC, Vogelsang $\mathrm{GB}$, et al. Consensus conference on clinical practice in chronic graftversus-host disease (GVHD): first-line and topical treatment of chronic GVHD. Biol Blood Marrow Transplant. 2010;16:1611-28.

126. Martin PJ, Storer BE, Rowley SD, Flowers ME, Lee SJ, Carpenter $\mathrm{PA}$, et al. Evaluation of mycophenolate mofetil for initial treatment of chronic graft-versus-host disease. Blood. 2009;113:5074-82.

127. Rezvani AR, Leisenring W, Martin PL, Flowers MED, Maloney DG, Chauncey TR, et al. Duration of immunosuppressive therapy for Chronic Graft-vs.-Host Disease (cGVHD) following nonmyeloablative allogeneic Hematopoietic Cell Transplantation (HCT). ASH Annu Meet Abstr. 2007;110:1071.

128. Lee SJ, Vogelsang G, Flowers MED. Chronic graft-versus-host disease. Biol Blood Marrow Transplant. 2003;9:215-33.

129. Lee SJ, Flowers ME. Recognizing and managing chronic graft-versushost disease. Hematol Am Soc Hematol Educ Prog. 2008;134-141.

130. Wolff D, Schleuning M, von Harsdorf S, Bacher U, Gerbitz A, Stadler M, et al. Consensus conference on clinical practice in chronic GVHD: second - line treatment of chronic graft-versushost disease. Biol Blood Marrow Transplant. 2011;17:1-17.

131. Brunkow ME, Jeffery EW, Hjerrild KA, Paeper B, Clark LB, Yasayko SA, et al. Disruption of a new forkhead/winged-helix protein, scurfin, results in the fatal lymphoproliferative disorder of the scurfy mouse. Nat Genet. 2001;27:68-73.

132. Bennett CL, Christie J, Ramsdell F, Brunkow ME, Ferguson PJ, Whitesell L, et al. The immune dysregulation, polyendocrinopathy, enteropathy, X-linked syndrome (IPEX) is caused by mutations of FOXP3. Nat Genet. 2001;27:20-1.

133. Humblet-Baron S, Sather B, Anover S, Becker-Herman S, Kasprowicz DJ, Khim S, et al. Wiskott-Aldrich syndrome protein is required for regulatory $\mathrm{T}$ cell homeostasis. $\mathrm{J}$ Clin Invest. 2007;117:407-18.

134. Kawano Y, Kim HT, Matsuoka K, Bascug G, McDonough S, Ho VT, et al. Low telomerase activity in CD4+ regulatory T cells in patients with severe chronic GVHD after hematopoietic stem cell transplantation. Blood. 2011;118:5021-30.

135. Dong S, Maiella S, Xhaard A, Pang Y, Wenandy L, Larghero J, et al. Multi-parameter single-cell profiling of human CD4+ FOXP3 + regulatory $\mathrm{T}$ cell populations in homeostatic conditions and during graft-versus-host disease. Blood. 2013.

136. Setoguchi R, Hori S, Takahashi T, Sakaguchi S. Homeostatic maintenance of natural Foxp3(+) CD25(+) CD4(+) regulatory T cells by interleukin (IL)-2 and induction of autoimmune disease by IL-2 neutralization. J Exp Med. 2005;201:723-35.

137. Pierson W, Cauwe B, Policheni A, Schlenner SM, Franckaert D, Berges J, et al. Antiapoptotic Mcl-1 is critical for the survival and niche-filling capacity of Foxp3(+) regulatory $\mathrm{T}$ cells. Nat Immunol. 2013;14:959-65.

138. Thiant S, Yakoub-Agha I, Magro L, Trauet J, Coiteux V, Jouet JP, et al. Plasma levels of IL-7 and IL-15 in the first month after myeloablative BMT are predictive biomarkers of both acute GVHD and relapse. Bone Marrow Transplant. 2010;45:1546-52.

139. De Bock M, Fillet M, Hannon M, Seidel L, Merville MP, Gothot A, et al. Kinetics of IL-7 and IL-15 levels after allogeneic peripheral blood stem cell transplantation following nonmyeloablative conditioning. PLoS One. 2013;8:e55876.

140. • Matsuoka K, Koreth J, Kim HT, Bascug G, McDonough S, Kawano Y, et al. Low-dose interleukin-2 therapy restores regulatory T cell homeostasis in patients with chronic graft-versus-host disease. Sci Transl Med. 2013;5:179ra43. An important study investigating Treg homeostasis after allogeneic HCTand demonstrating that lowdose IL-2 infusion promoted Treg homeostasis after allogeneic HCT.

141. Koreth J, Matsuoka K, Kim HT, McDonough SM, Bindra B, Alyea III EP, et al. Interleukin-2 and regulatory T cells in graftversus-host disease. N Engl J Med. 2011;365:2055-66.

142. Zhou H, Guo M, Bian C, Sun Z, Yang Z, Zeng Y, et al. Efficacy of bone marrow-derived mesenchymal stem cells in the treatment of sclerodermatous chronic graft-versus-host disease: clinical report. Biol Blood Marrow Transplant. 2010;16:403-12.

143. Weng JY, Du X, Geng SX, Peng YW, Wang Z, Lu ZS, et al. Mesenchymal stem cell as salvage treatment for refractory chronic GVHD. Bone Marrow Transplant. 2010;45:1732-40.

144. Matsuoka K, Kim HT, McDonough S, Bascug G, Warshauer B, Koreth $\mathrm{J}$, et al. Altered regulatory $\mathrm{T}$ cell homeostasis in patients with CD4+ lymphopenia following allogeneic hematopoietic stem cell transplantation. J Clin Invest. 2010;120:1479-93.

145. Humblet-Baron S, Castermans E, Vanbellighen JF, Hannon M, Jacobs N, Beguin Y, et al. What is the role for regulatory T-cells after nonmyeloablative conditioning? Biol Blood Marrow Transplant. 2008;14:136-7.

146. Castermans E, Hannon M, Dutrieux J, Humblet-Baron S, Seidel L, Cheynier R, et al. Thymic recovery after allogeneic hematopoietic cell transplantation with non-myeloablative conditioning is limited to patients younger than 60 years of age. Haematologica. 2011;96:298-306.

147. Introna M, Lucchini G, Dander E, Galimberti S, Rovelli A, Balduzzi A, et al. Treatment of graft versus host disease with mesenchymal stromal cells: a phase I study on 40 adult and pediatric patients. Biol Blood Marrow Transplant. 2013. doi:10. 1016/j.bbmt.2013.11.033.

148. Ball LM, Bernardo ME, Roelofs H, van Tol MJ, Contoli B, Zwaginga JJ, et al. Multiple infusions of mesenchymal stromal cells induce sustained remission in children with steroid-refractory, grade III-IV acute graft-versus-host disease. Br J Haematol. 2013.

149. Resnick IB, Barkats C, Shapira MY, Stepensky P, Bloom AI, Shimoni A, et al. Treatment of severe steroid resistant acute GVHD with mesenchymal stromal cells (MSC). Am J Blood Res. 2013;3:225-38. 